Selcuk Journal of Agriculture and Food Sciences

http://sjafs.selcuk.edu.tr/sjafs/index

Research Article
SJAFS

(2019) 33 (1), 52-61

e-ISSN: $2458-8377$

DOI:10.15316/SJAFS.2019.156

\title{
Tillage Effects on Energy Use Efficiency in Safflower Production in Middle Anatolia
}

\author{
Ergün ÇITIL ${ }^{1, *}, K^{*}$ azım ÇARMAN ${ }^{1}$, Tamer MARAKOĞLU ${ }^{1}$ \\ ${ }^{1}$ Selçuk University, Department of Agricultural Machineries and Technologies Engineering, Konya, Turkey
}

\begin{tabular}{l}
\hline ARTICLE INFO \\
\hline Article history: \\
Received date: 26.03 .2019 \\
Accepted date: 25.04 .2019 \\
\hline Edited by: \\
Osman ÖZBEK; Selçuk University, \\
Turkey \\
Anamika PANDEY; Selçuk University, \\
Turkey \\
Reviewed by: \\
Tanzer ERYILMAZ; Yozgat Bozok \\
University, Turkey \\
Gazanfer ERGÜNEŞ; Gaziosmanpaşa \\
University, Turkey \\
\hline Keywords: \\
Reduced Tillage \\
Direct Seeding \\
Energy Consumption \\
Energy Productivity \\
Safflower
\end{tabular}

\section{Introduction}

Energy, economics, and environment are mutually dependent. There is a close relationship between agriculture and energy. While agriculture uses energy, it also supplies it in the form of bio-energy. At present time, the productivity and profitability of agriculture depends upon energy consumption. Tillage is one of the highest power-required processes of the agricultural production. In addition, today, the high cost of energy forces the farmers to find alternative economic tillage methods. Therefor, it is necessary to apply reduced tillage or no-tillage (Pimentel et al., 1994; Alam et al., 2005; Marakoglu and Çarman, 2008).

In intensive tillage (conventional tillage including inversion of soil), one of the main disadvantages is the loss in the topsoil from $0-20 \mathrm{~cm}$ especially where agricultural land is exposed to water and wind erosion. The average wind erosion rate dropped 31 percent with protective farming practices in the world. Almost 1 billion tons of soil savings have occurred per year due to these changes in management. However, erosion is

\footnotetext{
* Corresponding author email: ecitil@selcuk.edu.tr
}

still occurring at a rate of 1.9 billion tons per year, and 108 million acres (29 percent of cropland) is still eroding at excessive rates (USDA- ARS, 1997).

Conservation of agriculture is a multi-dimensional approach the level of both energy usage and cost is minimized; and which involves the leaving of crop residues on surface to decompose in situ to protect water and soil. Direct seeding makes production profitable by decreasing the water and wind erosion. Although protecting of the soil is the main goal, soil moisture, energy usage, labor, and protection of machineries are also important (Köller, 2003).

Effective use of energy in agriculture is one of the conditions for sustainable agricultural production, since it provides financial savings, fossil resources preservation and air pollution reduction. Energy efficiency can be increased by decreasing the energy use from inputs such as fertilizer or tillage operations or by increasing the outputs such as crop yield. Aykas and Önal (1999) studied on how different tillage methods may affect both the yield of wheat and the amount of weed. According to results of the study, the highest yield value was $420 \mathrm{~kg} \mathrm{da}^{-1}$ for reduced tillage, and the lowest was $350 \mathrm{~kg} \mathrm{da}^{-1}$ for direct seeding. 
When compared with conventional tillage, direct seeding has less water consumption. In years when winter rains were too little, in lands with no weed, and without even any seedbed preparation, robust oilseed crops with deep root system such as safflower and flax can be grown (Mandal et al., 1994). Bayhan et al., (2001) reported that the lowest fuel consumption among different practices belong to direct seeding, and the highest yield value belong to combined tillage. In a similar study carried out by Yalçın and Çakır (2006), it was found that fuel consumption was measured as $60 \mathrm{~L}$ $\mathrm{ha}^{-1}$ in conventional tillage, and in direct seeding; it was obtained as $7.5 \mathrm{~L} \mathrm{ha}^{-1}$.

Çarman and Marakoğlu (2007) reported the highest total fuel consumption $\left(5.202 \mathrm{~L} \mathrm{da}^{-1}\right)$ was belonged to conventional tillage whereas the lowest $\left(0.972 \mathrm{~L} \mathrm{da}^{-1}\right)$ was belonged to direct seeding. Additionally, seedling emergence degrees were obtained as $73.02 \%$ at conventional tillage, $64.29 \%$ at reduced tillage and $62.7 \%$ at direct seeding.

Many researchers have studied energy and economic analyst is to determine the energy efficiency of plant production such as sugarcane in Morocco (Mrini, et al., 2001), wheat, maize, soybean, sugarbeet, sunflower, barley, oat in Italy (Sartori et al., 2005), cotton crops in Turkey (Dagistan, et al., 2009), sunflower in Greece (Kallivroussis et al., 2002), winter oilseed rape in Germany (Rathke and Diepenbrock, 2006) and wheat in Iran (Safa and Tabatabaeefar, 2002).
Due to the wide adaptation limits of the safflower plant, it can be grown in different ecologies. In addition, the roots can go into deep layers within the soil. Prickly plant growth increases the resistance to drought and heat (Dajue and Mundel 1996). With these properties, safflower is gaining importance as an oil plant which can be located in the cultivation of fallow land in dry land (Machado 2004). The most important advantage of safflower is that it is drought resistant and its agriculture is suitable for mechanization (Pinarkara 2007). In this study, the feasibility of safflower cultivation with wheat-safflower rotation was investigated in the fallow lands in Central Anatolia and especially in Konya which has a fallow area of 5.6 million decares. In addition, the effects of two different conservation tillage on the seedling emergence degree and grain yield values after seeding, and the energy balance of the safflower production have been determined.

\section{Materials and Methods}

Experiments were conducted in 2016 at Agricultural Research and Education Center of Selcuk University in the province of Konya (Seeding: 20th February 2016, Harvest: 2nd August 2016). The average monthly temperature and rainfall values in the experiment area are given in Table 1. Some of the important physical properties of the experiment field soils are given in Table 2.

Table 1

The meteorological data taken during the vegetation at the experiments

\begin{tabular}{lccccc}
\hline \multirow{2}{*}{ Month } & \multicolumn{3}{c}{ Temperature ${ }^{\circ} \mathrm{C}$} & \multirow{2}{*}{ Rain $(\mathrm{mm})$} & $\begin{array}{c}\text { Wind Speed } \\
\left(\mathrm{m} \mathrm{s}^{-1}\right)\end{array}$ \\
\cline { 2 - 4 } & Maximum & Minimum & Mean $n n$ & 1.0 \\
February & 20.6 & -8.3 & 6.6 & 3.4 & 1.3 \\
March & 25.6 & 7.8 & -5.6 & 37.2 & 1.3 \\
April & 27.9 & 4.4 & 0.7 & 10.2 & 1.4 \\
May & 30.3 & 5.2 & 15.7 & 31.2 & 1.6 \\
June & 33.7 & 7.5 & 21.9 & 36.4 & 1.4 \\
July & 36.6 & 11.5 & 24.3 & 2.8 & 1.3 \\
\hline Mean/Total & 29.1 & 4.6 & 10.6 & 121.2 & \\
\hline
\end{tabular}

Table 2

Some of the important physical properties of the experiment field soils

\begin{tabular}{lccc}
\hline Textural class & \multicolumn{3}{c}{$33.2 \%$ Salt; 31.5 \% Silt; 35.3 \% Clay } \\
Clay-Loam
\end{tabular}

Conventional and two conservation tillage treatments were performed on February. The treatments included:

-(CT) Conventional tillage (plough + Cultivator - float (2 times) + Seeding

-(RT) Reduced tillage: Vertical rotary tiller + Seeding

$\bullet$ (DS) No tillage: Direct Seeding
The equipments used in this study were operated with the standard tractor (Erkunt-Haşmet 110) of 80 $\mathrm{kW}$. Some of the machine's technical properties are given in Table 3. Safflower seeds (Dinçer) of 47.4 g. $1000^{-1}$ seeds were used in this study. Safflower seeds were sown for the experiment with $40 \mathrm{~kg} \mathrm{ha}^{-1}$ seed rate and at $40 \mathrm{~mm}$ sown depth. Row spacing was $12.5 \mathrm{~cm}$, seeding machine had a variable rate speed transmission 
system and toothed metering rollers that were used for seeding of different seeds. The speeds of the metering rollers of the seed drill were set at $10 \mathrm{rpm}$ at travelling speed of $1.75 \mathrm{~m} \mathrm{~s}^{-1}$. The direct seeder has a press wheel of $400 \times 75$ on the back of each seeder disc.

In order to determine the pulling force requirements of the machines, the draw pin of $30,000 \mathrm{~N}$ has been

Table 3

Some technical specifications of used machines

\begin{tabular}{lccccc}
\hline Machine & $\begin{array}{c}\text { Number of tide or } \\
\text { body }\end{array}$ & $\begin{array}{c}\text { Working width } \\
(\mathrm{cm})\end{array}$ & $\begin{array}{c}\text { Working depth } \\
(\mathrm{cm})\end{array}$ & $\begin{array}{c}\text { Travel speed } \\
(\mathrm{km} / \mathrm{h})\end{array}$ & Type \\
\hline Plough & 5 & 170 & 30 & 5.8 & $3 \mathrm{pt} \mathrm{hitch}$ \\
Cultivator + Float & $13 / 2$ & 310 & 20 & 6.7 & $3 \mathrm{pt} \mathrm{hitch}$ \\
Vertical Rotary Tiller & 10 & 250 & 25 & 2.7 & $3 \mathrm{pthitch}$ \\
Combined Seeder & 21 & 262 & 4 & 6.3 & $3 \mathrm{pthitch}$ \\
Direct Seeder & 20 & 284 & 4 & 6.3 & Pull-type \\
Spraying machine & - & 1000 & - & 6.5 & $3 \mathrm{pthitch}$ \\
\hline
\end{tabular}

To measure the fuel consumption, measurement device brand Rudolf Schmitt (0.5\% - accuracy) was used.

Surface relief was measured by using surface profile meter. This consisted of a set of vertical rods, spaced at $2.5 \mathrm{~cm}$ intervals, sliding through an iron bar of $100 \mathrm{~cm}$ length. The soil surface roughness was calculated by using the Kuipers equation; (Abo-Habaga 1990)

$$
R=100 \log _{10} S
$$

Where $\mathrm{R}$ is the surface roughness (\%) and $\mathrm{S}$ is the standard deviation ( $\mathrm{mm})$.

The standard deviation was estimated by measuring the distance between a constant horizontal surface and the soil surface over a set of $100 \mathrm{~cm}$.

In order to determine the penetration resistance, an Eijkelkamp analog penetrometer with $60^{\circ}$ cone angle was used. Measurements were made at the depth of 20 $\mathrm{cm}$ in $5 \mathrm{~cm}$ increments with five replications in each plot before and after soil tillage.

The soil shear testing device was used in order to determine the soil shearing strength which has a $10 \mathrm{~cm}$ diameter (D) and $12 \mathrm{~cm}$ height (h). Torque arm having a measuring range of 0-80 Nm was impaled on shear vane. The maximum torque $(\mathrm{T})$ was obtained via soil shear testing device as shear stress $(\tau)$ was obtained by the following equation (Okello 1991):

$$
\tau=\frac{T}{\pi D^{2}\left(\frac{h}{2}+\frac{D}{6}\right)}
$$

In order to determine seedling emergence, the experiment field was observed throughout the emergence time and along with the beginning of the emergences, emergence counts were taken at two days intervals at the distance of $300 \mathrm{~cm}$ from three separate rows. The values of average emergence day (MED), emergence attached to three-point link arms of the tractor. The data logger that collects 20 data per seconds was used. In trials, nitrogen of $86.8 \mathrm{~kg} \mathrm{ha}^{-1}$ and phosphorus of $59.8 \mathrm{~kg} \mathrm{ha}^{-1}$ were applied together with seeding. In addition, $2.5 \mathrm{~kg} \mathrm{ha}^{-1}$ herbicide was applied for weed control. rate index (ERI), and seedling emergence degree (PE) were calculated by using the values obtained from the counts in the equations given in Bilbro and Wanjura, (1982):

$$
\begin{gathered}
M E D=\frac{N_{1} D_{1}+N_{2} D_{2}+\ldots+N_{n} D_{n}}{N_{1}+N_{2}+\ldots+N_{n}} \\
E R I=\frac{\text { Total emergence in } 1 \text { meter long band }}{M E D} \\
P E=\frac{\text { Total emergence in } 1 \text { meter long band }}{\text { Number of seeds sowed in } 1 \text { meter long band }} \times 100
\end{gathered}
$$

Where MED is mean emergence day; ERI is emergence rate index, seedlings day ${ }^{-1} \mathrm{~m}^{-1}$; PE is percentage of emergence, $\% ; \mathrm{N}_{1} \ldots \mathrm{n}$ is number of seedlings emerging since the time of previous count; $D_{1} \ldots n$ is number of days after the seeding.

In order to determine the number of seeds sown in a 1 meter line length, the machines were set to give 40 $\mathrm{kg} \mathrm{ha}^{-1}$ seed rate. The number of seeds dropped from different furrow opener was determined as 5 replications. The average seed number dropped from a furrow opener to the $1 \mathrm{~m}$ line length was found to be 11 .

The safflower seed and biomass energy equivalent were measured by a calorimeter. For this EN 61010, EN 50082, EN 55014 and EN 60555 standards are taken into account.

Randomized Complete-Block Design with three replicates has been performed in this study. Human labor, machinery, chemical fertilizers, diesel fuel and seed energy have been computed inputs. In order to evaluate energy efficiency of agricultural production, energy equivalents of the inputs and outputs used in the safflower production are given in Table 4. Energy parameters are given in Table 5. 
Table 4

Equivalent energies

\begin{tabular}{lccc}
\hline Properties & Unit & Equivalent energy Mj/unit & Reference \\
\hline Inputs & & & Kizllaslan (2009), Barut et al. (2011) \\
\hline Labor & $\mathrm{h}$ & 2.3 & Doering (1980), Barut et al. (2011) \\
Tractor & $\mathrm{h}$ & 158.3 & Doering (1980), Barut et al. (2011) \\
Machine & $\mathrm{h}$ & 121.3 & (Reinhardt., 1993) \\
Fuel-Oil & $\mathrm{L}$ & 41 & (Çanakç1 et al., 2005)(Mandal et al ., 2002) (Singh,2002) \\
Herbicide & $\mathrm{kg}$ & 120 & (Bojaca and Shrevens.,2010) (Öztürk.,2011) \\
Fertilizer (N) & $\mathrm{kg}$ & 60.6 & (Kaltschmitt and Reinhardt., 1997) \\
Fertilizer (P) & $\mathrm{kg}$ & 15.7 & \\
Seed & $\mathrm{kg}$ & 24.37 & \\
\hline Outputs & & & \\
\hline Yield & $\mathrm{kg}$ & 23.99 & \\
Biomass & $\mathrm{kg}$ & 17.18 & \\
\hline
\end{tabular}

Table 5

Energy parameters (Tabata baeefar, et al., 2009; Zangeneh, et al., 2010; Mousavi-Avval et al., 2011; Öztürk, 2011)

\begin{tabular}{lcc}
\hline Parameter & Unit & Definitions \\
\hline Total energy input & MJ/ha & EI \\
Total energy output & MJ/ha & EO \\
Yield of net energy & MJ/ha & Total energy output - Total energy input \\
The rate of output / input & $\%$ & Total energy output / Total energy input \\
The rate of net energy & $\%$ & Net energy efficiency / Total energy input \\
Energy efficiency & $\mathrm{kg} / \mathrm{MJ}$ & Grain and biomass yield / Total energy input \\
Energy required for the unit product & $\mathrm{kg} / \mathrm{MJ}$ & Total energy input / Grain and biomass yield \\
\hline
\end{tabular}

\section{Results and Discussion}

Before the trial, the amount of stubble was $885-920$ $\mathrm{m}^{2}$ in the plots. The weed coating rate was found to be between $1-1.3 \%$ in the field, and this rate will not affect the efficiency negatively, thus weed struggle has not been done directly before planting, while not economical to fight with chemical methods was thought.

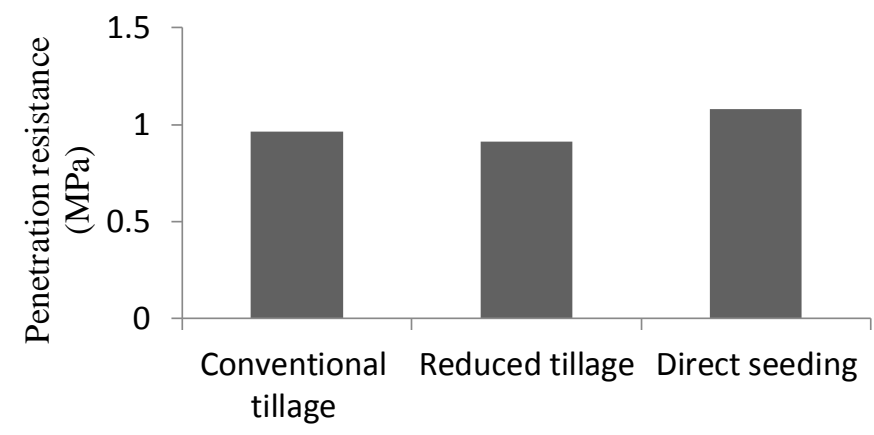

Figure 1

The effects on penetration resistance of different applications.

The values of soil cut resistance ranged from 1.11

to $1.99 \mathrm{Ncm}^{-2}$. The soil cut resistance values obtained from the applications are given in Figure 2.
When the applications were evaluated in terms of the effect of penetration resistance in $0-20 \mathrm{~cm}$ depth region of soil, the greatest penetration resistance was seen in direct seeding as expected, while the lowest value was observed in reduced tillage application (Figure 1). The penetration resistance of the soil varied between $0.91 \mathrm{MPa}$ and $1.07 \mathrm{MPa}$ depending on the application of soil tillage. 


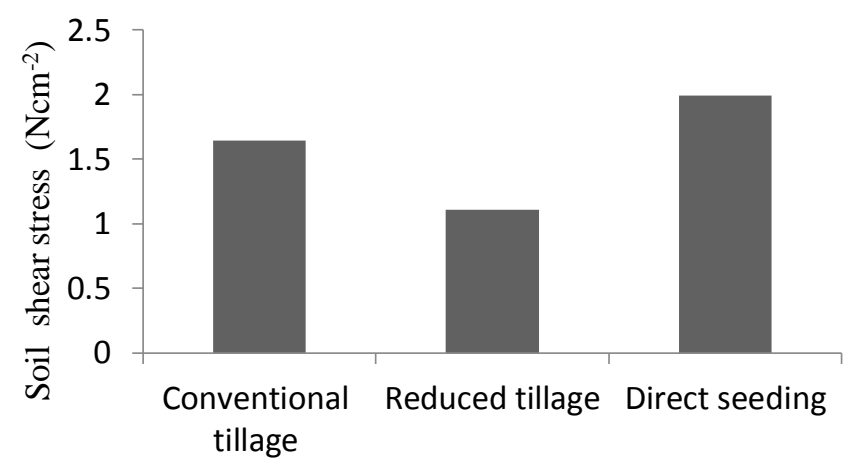

Figure 2

The effects on soil shear stress of different applications

Surface roughness's values of the application soil ranged from $7.78 \%$ to $25 \%$. (Figure 3 ). In conventional application, according to the surface roughnessü, val-

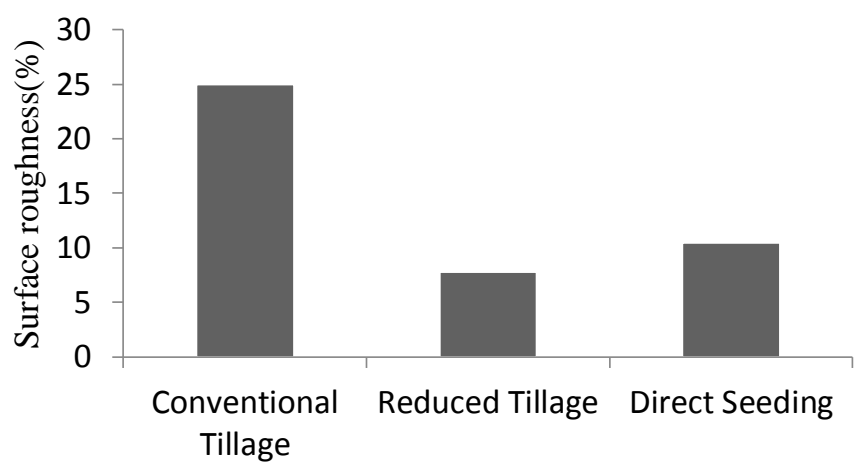

Figure 3

The effects on surface roughness values of different applications

The specific draw force requirements of the machines used in the three different applications of safflower production is given in Figure 4. The highest

value in terms of specific draw force is obtained in the plough, while the lowest value is obtained in the classic combined seed drill. ues were $221.3 \%$ higher than reduced tillage. In addition to this, these were $138.6 \%$ higher than direct seeding.

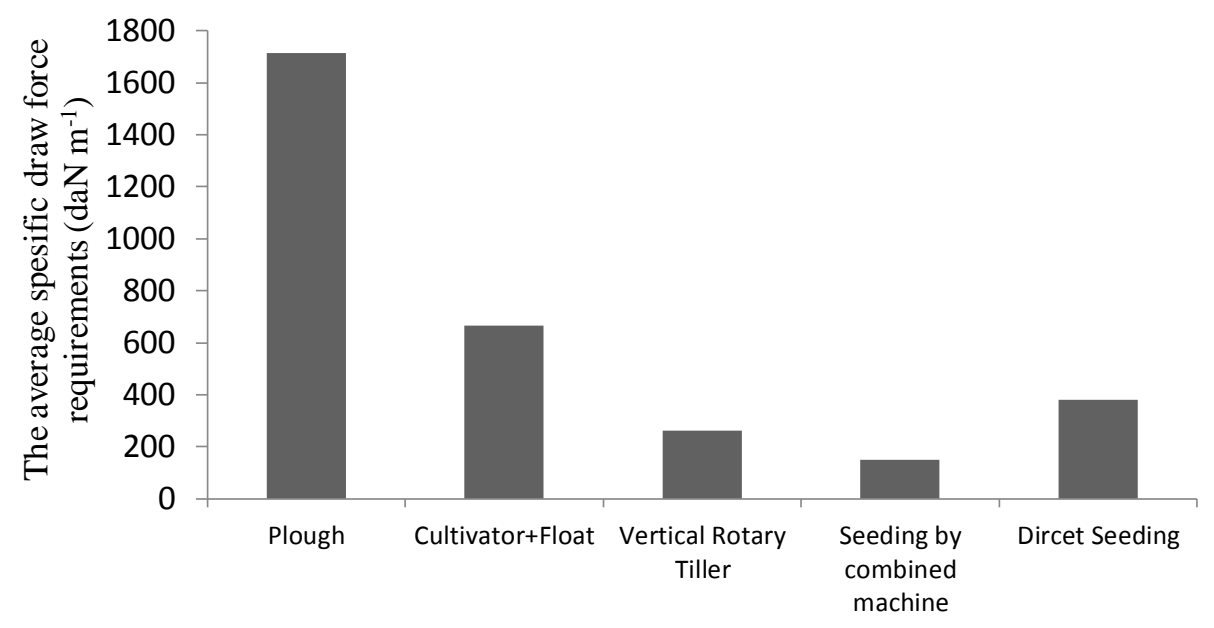

Figure 4

The average specific draw force of equipments

According to Marakoğlu and Çarman (2008), because of the two years of studies on reduced tillage and direct seeding applications in wheat production, the highest specific draw force value of the machines used was reported on the plow and the lowest value was 
application in vertical rotary tiller and the lowest consumption was obtained with $3 \mathrm{~L} \mathrm{ha}^{-1}$ application from spraying machine. By using the direct seeding machine, the fuel consumption of the tractor was $11.76 \%$ higher than the classic seeding machine. Marakoğlu and Çarman (2008) reported that in a two-year study of reduced tillage and direct seeding applications in wheat

Table 6

Total fuel consumption values of used equipment and applications

\begin{tabular}{lccc}
\hline Equipment & $\begin{array}{c}\text { Conservational Tillage } \\
\mathrm{L} \mathrm{ha}^{-1}\end{array}$ & $\begin{array}{c}\text { Reduced Tillage } \\
\mathrm{L} \mathrm{ha}^{-1}\end{array}$ & $\begin{array}{c}\text { Direct Seeding } \\
\mathrm{L}^{-\mathrm{ha}^{-1}}\end{array}$ \\
\hline Moldboard plought & 20,7 & - & - \\
Cultivator + Float (two times) & $12.3 \times 2$ & - & - \\
Vertical Rotary Tiller & - & 20.8 & - \\
Combined Seed Drill & 8.5 & 8.5 & - \\
Direct Seed Machine & - & - & 9.5 \\
Spraying machine & 3 & 3 & 3 \\
\hline Total & 56.8 & 32.3 & 12.5 \\
\hline
\end{tabular}

When the applications were evaluated in terms of total fuel consumption, the highest fuel consumption was seen in the conventional application and the lowest was in the direct seeding application. In conventional application, the total fuel consumption was 4.54 times higher than direct seeding. According to Akbarnia and Fahranı (2014), they analyzed the fuel consumption of different tillage applications and in conventional tillage, reduced tillage and direct seeding it was found 59.33 $\mathrm{L} \mathrm{ha}^{-1}, 29.67 \mathrm{~L} \mathrm{ha}^{-1}, 14.33 \mathrm{~L} \mathrm{ha}^{-1}$ respectively. Marakoğlu and Çarman (2017) reported that fuel consumption values were $50 \%$ decreased in reduced tillage application in wheat.

Bonari et al. (1995) insisted on their research to determine the yield and soil's physical properties by using the combined machines for different tillage

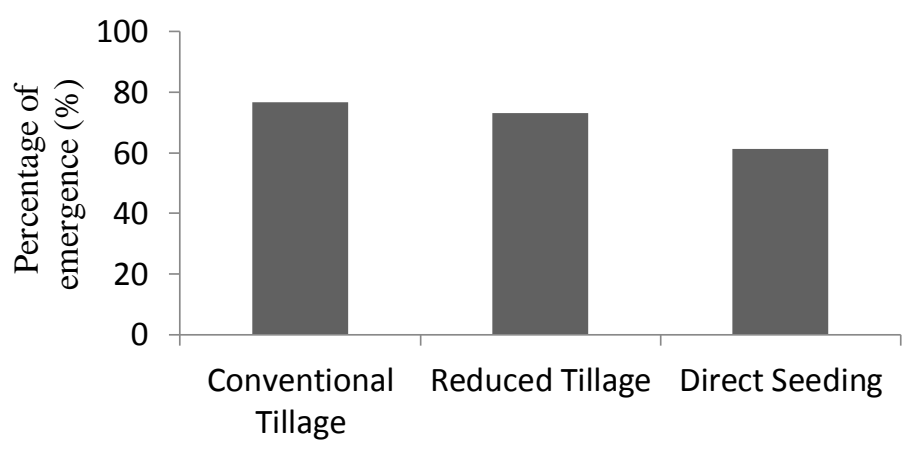

Figure 5

Percentage of emergence of applications

The grain yield values of the applications ranged between $822-921 \mathrm{~kg} \mathrm{ha}^{-1}$ (Figure 6). The highest grain yield was obtained in the conventional application, while it decreased by $1.95 \%$ in reduced tillage and by $10.7 \%$ in direct seeding method. According to Meral (1996), depending on Çukurova conditions, seed yield was $1.258 \mathrm{~kg} \mathrm{ha}^{-1}$ which was observed in Yenice, Dinçer and 5-154-2 varieties in barren and sole condi- production, the highest fuel consumption was $19.9 \mathrm{~L}$ $\mathrm{ha}^{-1}$ from vertical rotary tiller machine, the lowest fuel consumption was $8.1 \mathrm{~L} \mathrm{ha}^{-1}$ from a minimum combined seeding machine and the fuel consumption of the direct seeding machine was higher than $12.3 \%$ to the classic seeding machine. methods in order to investigate the level of energy consumption under different conditions for tillage methods. Reduced tillage method provided less than $55 \%$ fuel consumption but there was no importance for yield in tillage methods. Similarly, Craciun et al. (2004) reported $60 \%$ reduction in fuel consumption by reduced tillage applications.

Mean germination time (MED) values ranged from 38.3 days to 43.3 days. The germination ratio value was found between 0.42 and $0.71 \mathrm{~m}^{-1} \mathrm{day}^{-1}$. While comparing percentage of emergence applications, the highest percentage of emergence was found in conventional application with $76.8 \%$ and the lowest in direct seeding application was $61.2 \%$. (Figure 5). The effect of the applications on the percentage of emergence was found to be significant $(\mathrm{P}<0.01)$. 
be significant $(\mathrm{P}<0.01)$. Prihar et al., (1975) defined that high yield in conventional tillage method is related to good root growth and high amount of water used, and the hard soil layer under working depth in reduced tillage area may prevent root growth and water use.

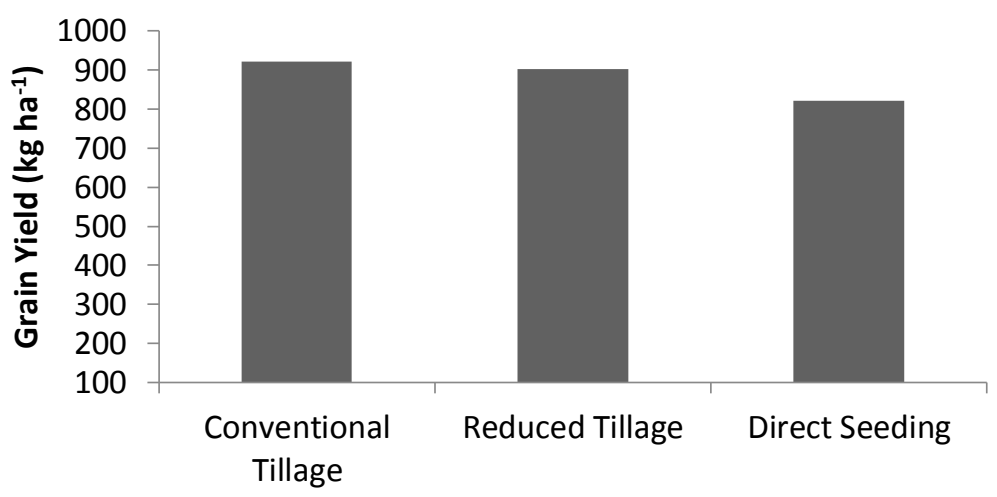

Figure 6

Grain yield values of applications

Akbarnia and Farhani (2014) investigated the effects of different tillage applications on wheat yield. The grain yield values were $8.07 \mathrm{t} \mathrm{ha}^{-1}$ in conventional soil tillage and $7.90 \mathrm{tha}^{-1}$ in reduced tillage, in addition to these, it was $6.33 \mathrm{t} \mathrm{ha}^{-1}$ in direct seeding.

When Table 7 is examined, the share of the most production inputs in the applications are followed by the fertilizer energy, and the fuel, seed, herbicide and machinery energies respectively. In direct sowing the seed energy input is higher than the fuel energy input. Hamedani et al., (2011) stated that energy consumed in production of grapes was 45,213. $66 \mathrm{MJ} \mathrm{ha}^{-1}$ and this energy is dividing to outputs so the highest level was $37.25 \%$ for fertilizer. Konak et al., (2004) stated that the highest rate of total energy inputs in maize production is fertilizer energy followed by the seed, instrument-machine and fuel-oil energies.

Baran and Ark. (2016) stated while comparing the different tillage and seeding methods in the production of silage corn, fertilizer inputs were the highest value of the production inputs in Cukurova region.

Baran ve Karaağaç (2014) determined that irrigation energy has the highest value in consumption rate and it was $30.36 \%$ in the second product sunflower production. In addition, fertilizer energy rate was 28.78 $\%$ and fuel-oil energy rate was $24.74 \%$.

Conventional application, in reduced tillage application and direct seeding application, the share of the fuel-oil energy values in the total energy input was determined as $22.86 \%, 14.40 \%$ and $6.20 \%$ respectively. Moreover, the conventional application has about 3.69 times more fuel-oil energy input than the direct seeding method. When the applications were examined in terms of the energy value required for the production of one $\mathrm{kg}$ of product, the best result was obtained by direct seeding with $3.44 \mathrm{MJ} \mathrm{kg}^{-1}$ followed by reduced tillage application, and conventional application, respectively. Direct seeding application has the lowest energy input in terms of labor, tractor and machinery inputs. According to Marakoğlu and Çarman (2017), same results were observed from wheat production at direct seeding in Middle Anatolia.

In agricultural mechanization applications, unit energy consumption can be reduced by using machines such as combined machines and direct seeding machines. However, the application of protective soil tillage methods helps to protect the soil's organic structure and prevents soil erosion (Hargrave, 1982).

The highest value of net yield energy obtained from reduced tillage was 40,917.16 $\mathrm{MJ} \mathrm{ha}^{-1}$ and from conventional applications was 40,427.49 $\mathrm{MJ} \mathrm{ha}^{-1}$, in addition to these, from direct seeding it was 38,591.87 MJ $\mathrm{ha}^{-1}$. In other words, the highest value of energy obtained from direct seeding was $0.29 \mathrm{~kg} \mathrm{MJ}^{-1}$ and from reduced tillage it was $0.28 \mathrm{~kg} \mathrm{MJ}^{-1}$; in addition to these, from conventional applications it was $0.25 \mathrm{~kg} \mathrm{MJ}^{-1}$. Marakoğlu and Çarman (2017) stated that the value of yield energy obtained from reduced tillage in wheat production was $0.82-0.93 \mathrm{~kg} \mathrm{MJ}^{-1}$ and from conventional applications it was $0.83 \mathrm{~kg} \mathrm{MJ}^{-1}$. Moghimi et al., (2013) found that the value of net yield energy was 54 937.18 $\mathrm{MJ} \mathrm{ha}^{-1}$ and the yield energy was $0.13 \mathrm{~kg} \mathrm{MJ}^{-1}$ in production of wheat. 
Table 7

Energy balance

\begin{tabular}{|c|c|c|c|c|c|c|}
\hline \multirow{2}{*}{ A.Input } & \multicolumn{2}{|c|}{ Conventional Tillage } & \multicolumn{2}{|c|}{ Reduced Tillage } & \multicolumn{2}{|c|}{ Direct Seeding } \\
\hline & $\mathrm{MJ} \mathrm{ha}^{-1}$ & $\%$ & $\mathrm{MJ} \mathrm{ha}^{-1}$ & $\%$ & $\mathrm{MJ}_{\mathrm{ha}}{ }^{-1}$ & $\%$ \\
\hline Labor & 8.39 & 0.08 & 6.90 & 0.08 & 2.21 & 0.03 \\
\hline Tractor & 206.26 & 2.03 & 203.88 & 2.22 & 65.25 & 0.79 \\
\hline Machine & 168.19 & 1.65 & 186.35 & 2.03 & 217.89 & 2.63 \\
\hline Fuel-oil & 2328.80 & 22.86 & 1324.30 & 14.40 & 512.50 & 6.20 \\
\hline Herbicide & 300.00 & 2.95 & 300.00 & 3.26 & 300.00 & 3.63 \\
\hline Fertilizer $(\mathrm{N})$ & 5260.80 & 51.65 & 5260.80 & 57.21 & 5260.80 & 63.60 \\
\hline Fertilizer $(\mathrm{P})$ & 938.86 & 9.22 & 938.86 & 10.21 & 938.86 & 11.35 \\
\hline Seed & 974.80 & 9.57 & 974.80 & 10.60 & 974.80 & 11.78 \\
\hline Total input & 10186.10 & 100.00 & 9195.89 & 100.00 & 8272.31 & 100.00 \\
\hline \multicolumn{7}{|l|}{ B. Output } \\
\hline Yield grain & \multicolumn{2}{|c|}{22094.79} & \multicolumn{2}{|c|}{21662.97} & \multicolumn{2}{|c|}{19719.78} \\
\hline Yeld biomass & \multicolumn{2}{|c|}{28518.80} & \multicolumn{2}{|c|}{28450.08} & \multicolumn{2}{|c|}{27144.4} \\
\hline Total output & \multicolumn{2}{|c|}{50613.59} & \multicolumn{2}{|c|}{50113.05} & \multicolumn{2}{|c|}{46864.18} \\
\hline \multicolumn{7}{|l|}{ Parameters } \\
\hline EI & \multicolumn{2}{|c|}{10186.10} & \multicolumn{2}{|c|}{9195.89} & \multicolumn{2}{|c|}{8272.31} \\
\hline EO & \multicolumn{2}{|c|}{50613.59} & \multicolumn{2}{|c|}{50113.05} & \multicolumn{2}{|c|}{46864.18} \\
\hline Yield of net energy $\left(\mathrm{Mj} \mathrm{ha}^{-1}\right)$ & \multicolumn{2}{|c|}{40427.49} & \multicolumn{2}{|c|}{40917.16} & \multicolumn{2}{|c|}{38591.87} \\
\hline The rate of output / input (\%) & \multicolumn{2}{|c|}{4.97} & \multicolumn{2}{|c|}{5.45} & \multicolumn{2}{|c|}{5.67} \\
\hline The rate of net energy (\%) & \multicolumn{2}{|c|}{3.97} & \multicolumn{2}{|c|}{4.45} & \multicolumn{2}{|c|}{4.67} \\
\hline Energy efficiency $\left(\mathrm{kg} \mathrm{MJ}^{-1}\right)$ & \multicolumn{2}{|c|}{0.25} & \multicolumn{2}{|c|}{0.28} & \multicolumn{2}{|c|}{0.29} \\
\hline $\begin{array}{l}\text { Energy requirement per pro- } \\
\text { duct unit }\left(\mathrm{MJ} \mathrm{kg}^{-1}\right)\end{array}$ & \multicolumn{2}{|c|}{3.95} & & 59 & & \\
\hline
\end{tabular}

Obtaining from the reduced tillage application in the unit area the net yield energy was $1.21 \%$ more than conventional application and $6.02 \%$ more than the direct seeding applications. When the applications are evaluated in terms of energy efficiency, it was determined that direct seeding application rate was $16 \%$ higher than the conventional applications and it was $12 \%$ higher than the reduced tillage applications.

Çanakçı et all (2005), estimated that the energy rate of wheat production was 2.8 and of maize production was 3.8 in Antalya.

Karaağaç et all (2011), tried to make the energy balance of wheat and maize in a company, and the number of values related to wheat, specific energy, energy sources of these plants is $3.50,4.20 \mathrm{MJ} \mathrm{kg}^{-1}$ and $0.24 \mathrm{~kg} \mathrm{MJ}^{-1}$, corn $6.54,2.25 \mathrm{MJ} \mathrm{kg}^{-1}$ and $0.44 \mathrm{~kg} \mathrm{MJ}^{-1}$.

The following evaluations can be made from these assessments.

-The output/input ratio obtain from direct seeding was $14.11 \%$ higher than the conventional application and $4.04 \%$ higher than the reduced tillage application.

-Although low yield was obtained from direct seeding method, the input quantity was less than other methods, in direct seeding the net energy ratio was $17.6 \%$ higher than the conventional applications and it was $4.94 \%$ higher than the reduced tillage.

-Net energy yield was at the highest rate at reduced tillage application and it was ordered by conventional application and direct seeding, respectively. Thus it is important for the spreading of protective soil tillage methods.

-In conventional application, energy consumption for the unit product was detected to be $14.8 \%$ higher than direct seeding and $10.02 \%$ higher than reduced tillage.

- The fact that the energy required for the unit product amount was less than the other applications of direct seeding application, it was effective in the possibility to enable the establishment of an alternative application in the economic conditions.

- If the yield values are low from applications in one year, the average rainfall and temperature values of the region may be low during the vegetation period and year.

-It is possible that direct seeding method is more advantageous than other methods according to the fuel consumption, time, labor and work success and at large production areas works can be done in a timely manner, depends on it, waste of time can be reduced.

-Production of safflower can be done in dry agricultural regions of Middle Anatolia where fallow application is done in agricultural production.

\section{References}

Abo-Habaga MM (1990). A Comperative Study on Three Chisel-Plougk Share Forms. Misr. J. Ag. Eng., 7(4), 378-383 
Akbarnia A, Farhani F (2014). Study of fuel consumption in three tillage methods. Research in Agricultural Engineering, 60: 142-147.

Alam MS, Alam MR, Islam KK (2005). Energy flow in agriculture: Bangladesh. American Journal of Environmental Sciences, 1(3): 213-20.

Aykas E, Önal İ (1999). Effect of Different Tillage Seeding and Weed Control Methods on Plant Growth and Wheat Yield. 7. International Congress on Mechanization and Energy in Agriculture, 119124, Adana.

Baran MF, Karaağaç HA (2014). Kırklareli Koşullarında İkinci Ürün Ayçiçeği Üretiminde Enerji Kullanım Etkinliğinin Belirlenmesi. Türk Tarım ve Doğa Bilimleri Dergisi, 2: 117-123.

Baran MF, Karaağaç HA, Gökdoğan O, (2016). Kışlık Ara Ürün Sonrası (Buğday - Fiğ) İkinci Ürün Olarak Yetiştirilen Silajlık Mısır Üretiminde Farklı Toprak İşleme Ve Ekim Yöntemlerinin Enerji Bilançosu. Adnan Menderes Üniversitesi Ziraat Fakültesi Dergisi, 13(1): 1-6, Aydın.

Barut ZB, Ertekin C, Karaağaç HA (2011). Tillage Effects on Energy Use for Corn Silage in Mediterranean Coastal of Turkey. Energy 36(9):5466-5475.

Bayhan Y, Gönülol E, Yalçın H, Kayışoğlu B (2001). İkinci Ürün Silajlık Mısır Tarımında Azaltılmış Toprak İşleme ve Doğrudan Ekim Uygulamaları. Tarımsal Mekanizasyon 20. Ulusal Kongresi, 96101, Şanlıurfa.

Bilbro JD, Wanjura DF (1982). Soil crusts and cotton emergence relationship. Transaction of the ASAE, 25, 1484-1489.

Bojoca CR, Schrevens E (2010). Energy assessment of peri-urban horticulture and its uncertainty: case study for Bogota, Colombia. Energy; 35:2019-18

Bonari E, Mazzoncini M, Peruzzi A (1995). Effects of conventional and minimum tillage on winter oilseed rape (Brassica napus L.) in a sandy soil. Soil and Tillage Research, 33: 91-108.

Çanakcı M, Topakcı M, Akıncı I, Özmerzi A (2005). Energy Use Pattern of Some Field Crops and Vegetable Production: Case Study for Antalya Region, Turkey. Energy Conversion Management, 46: 655666

Craciun V, Nitescu E, Balan O, Magureanu M (2004). Combined machines for seedbed preparation and sowing a necessity for applying advanced technologies in crop production. Balkan Agricultural Engineering Review, 6: 1-5.

Çarman K, Marakoğlu T (2007). Nohut Üretiminde Azaltılmış Toprak İşleme Ve Direk Ekim. Uygulamalarının Karşılaştırılması. Koruyucu Toprak İşleme ve Doğrudan Ekim Çalıştayı, 93-104, İzmir

Dagistan E, Akcaoz H, Demirtas B, Yilmaz Y (2009). Energy usage and benefit-cost analysis of cotton production in Turkey. African Journal of Agricultural Research, 4(7): 599-604.
Dajue L, Mundel HH (1996). Safflower: Carthamus tinctorius L. promoting the conservation and use of under utilized and neglected crops. Institute of Plant Genetics and Crop Plant Research, Gatersleben/International Plant Genetic Resources Institute, Rome, Italy

Doering OC (1980). Accounting for energy in farm machinery and buildings. In:Pimentel David, editor. Handbook of Energy Utilization in Agriculture.FL, USA: CRC Press, Inc, ISBN 0-8493-2661-3;. p. 914.

Hamedani SR, Keyhani A, Alimardani R (2011). Energy use patterns and econometric models of grape production in Hamadan province of Iran. Energy, $36,6345-6351$.

Hargrave WL (1982). Influence of tillage practices on the fertility status of acid soil double-cropped to wheat and soybean. Agronomy Journal,74:684687.

Kallivroussis, L., Natsis, A., Papadakis, G., 2002. The energy balance of sunflower production for biodiesel in Greece. Biosystems Engineering, 81(3): 347-54.

Kaltschmitt M, Reinhardt GA (1997). Nachwachsende Energieträger - Grundlagen, Verfahren, ökologische Bilanzierung, Braunschweig.

Karaağaç MA, Aykanat S, Çakır B, Eren Ö, Bereket Z, Turgut MM (2011). Energy balance of wheat and maize crops production in Haciali undertaking. 11th International Congress on Mechanization and Energy in Agriculture Congress, 1-10, İstanbul.

Kizilaslan H (2009). Input-Output Energy Analysis of Cherries Production in Tokat Province of Turkey. Applied Energy 86: 1354-1358.

Konak M, Marakoğlu T, Özbek O (2004). Misır Üretiminde Enerji Bilançosu Selçuk Üniversitesi Ziraat Fakültesi Dergisi 18(34): 28-30

Köller K (2003). Conservation Tillage-Technical, Ecological and Economic Aspects. Koruyucu Toprak İşleme ve Doğrudan Ekim Çalıştayı, 9-34, İzmir.

Machado S (2004). Potential Alternative Crops for Eastern Oregon. Oregon Agricultural Experiment Station Special Report 1054: 84-102.

Mandal BK, Saha A, Dhara MC, Bhunia SR (1994). Effects of zero and conventional tillage on winter oilseed crops in West Bengal. Soil and Tillage Research 29: 49-57

Mandal KG, Saha KP, Ghosh PK, Hati KM, Bandyopadhyay KK (2002). Bioenergy and Economic Analysis of Soybean-Based Crop Production Systems in Central India. Biomas Bioenergy 23(5): 337-345

Marakoğlu T, Çarman K (2008). Buğday Üretiminde Azaltılmış Toprak İşleme Ve Direk Ekim Uygulamaları. Selçuk Üniversitesi Ziraat Fakültesi Dergisi, 22 (46): 73-76 
Marakoğlu T, Çarman K (2017). A Comparative Study on Energy Efficiency of Wheat Production Under Different Tillage Practices in Middle Anatolia of Turkey. Fresenius Environmental Bulletin, 26 (5), 3163-3169

Meral Y (1996). Çukurova Koşullarında Taban ve Kıraç Alanlarda Aspir Çeşitlerinin Tarımsal Özellikleri ile Çiçek Verimlerinin Araştırılması. Ç.Ü. Zir. Fak. Yüksek Lisans Tezi (basılmamış), Adana.

Moerschner J, Gerewitt B (1998). Energiebilanzen von Raps bei unterschiedlichen anbauintensitaten. Landtechnik 6/98, p.384-5

Moghimi MR, Alasti BM, Drafshi MAH (2013). Energy input-output and study on energy use efficiency for wheat production using DEA technique. International Journal of Agriculture and Crop Sciences, 5(18), 2064-2070.

Mousavi-Avval SH, Rafiee S, Jafari A, Mohammadi A (2011). Optimization of energy consumption for soybean production using Data Envelopment Analysis (DEA) approach. Applied Energy, 35, 21562164

Mrini M, Senhaji F, Pimentel D (2001). Energy analysis of sugarcane production in Morocco. Environment, Development and Sustainability, 3: 109-26.

Okello JA (1991). A Review of Soil Strength Measurement Techniques for Prediction of TerrainVehicle Performance. Journal of Agriculture Engineering Research, 50: 129-155.

Öztürk Ö, Ada R, Akınerdem F (2009). Bazı Aspir Çeşitlerinin Sulu Ve Kuru Koşullarda Verim Ve Verim Unsurlarının Belirlenmesi. Selçuk Üniversitesi, Selçuk Tarım ve Gıda Bilimleri Dergisi, 23 (50): 16-27

Öztürk HH (2011). Bitkisel Üretimde Enerji Yönetimi. Hasad Yayıncılık Ltd.Şti. ISBN: 978-975-8377-787

Pimentel D, Herdendorf M, Eisenfeld S, Olander L, Carroquino M, Corson C (1994). Achieving a secure energy future: environmental and economic issues. Ecol Econ, 3: 201-19.

Pınarkara M (2007). Tarım ve Tarıma Dayalı Sanayide Suyun Önemi. Konya'da Tarım ve Tarımsal Sanayi
Sorunlarının Tesbiti Sempozyumu, 171-184, Konya.

Prihar SS, Singh P, Gajri PR (1975). Effect of simulated plow-sole on water uptake and yield of dryland wheat. Agronomy Journal, 67: 364-373.

Rathke GW, Diepenbrock W (2006). Energy balance of winter oilseed rape (Brassica napus L.) cropping as related to nitrogen supply and preceding crop. The European Journal of Agronomy, 24: 35-44.

Reinhardt GA (1993). Energie und $\mathrm{CO}_{2}$ Bilanzierung nachwchsender Rohdtoffe. 2nd. Edition Vieweg, Braunschweig/Wiesbaden

Safa M, Tabatabaeefar A (2002). Energy consumption in wheat production in irrigated and dry land farming. International Agricultural Conference, 28-30, Wuxi, China.

Sartori L, Basso B, Bertocco M, Oliviero G (2005). Energy use and economice valuation of a three year crop rotation for conservation and organic farming in NE Italy. Biosystems Engineering, 91(2): 24556.

Singh JM (2002). On Farm Energy Use Pattern in Different Cropping Systems in Haryana, India. Master of Sience Germany: İnternational İnstitute of Management University of Flensburg.

Tabatabaeefar A, Emamzadeh H, Varnamkhasti MG, Rahimizadeh R, Karimi M (2009). Comparison of energy of tillage systems in wheat production. Energy, 34, 41-45.

USDA ARS (1997). Predicting Soil Erosion by Water: a Guide to Conservation Planning with the Revised Universal Soil Loss Equation (RUSLE), Ag Handbook 703, 383 pp.

Yalçın H, Çakır E (2006). Tillage Effect and Energy Efficiencies of Subsoling and Direct Seeding in Light Soil on Yield of Second Crop Corn for Silage in Western Turkey. Soil and Tillage Research, 90: 250-255.

Zangeneh M, Omid M, Akram AA (2010). Comparative study on energy use and cost analysis of potato production under different farming technologies in Hamadan province of Iran. Energy, 35, 2927-2933. 